\title{
SALVE ET ITERUM SALVE
}

Dit is vir die Redaksie 'n besondere voorreg om met hierdie uitgawe dank en waardering te betuig aan 'n fiere eksponent van die wysbegeerte op Calvinistiese grondslag. Die feit dat prof. Stoker een van die oorspronklike oprigters en vir drie jaar lank hoofredakteur van hierdie blad was plaas hom nog verder in ' $n$ besondere posisie van eer. In akademiese kringe is daar nog hoë verwagtings van prof. Stoker: die verdere uitbouing van sy besondere stempel op die Christelike wysgerige denke bly 'n dringende noodsaaklikheid. In ons dank is daar dus nie die weemoed van finale afskeid nie: volgens prof. Stoker se eie woorde is hierdie maar 'n caesura (onderbrekings- of ruspunt in die versreël) soos ook vorige caesurae in sy lewe. Ons addendum hierby is: gewoonlik kom die skoonste deel en hoogtepunt van 'n versreël na die hoofcaesura!

Vir sy aandeel aan „Koers” tot so ver ons innige dank aan prof. Stoker: wat skoon, goed en edel is gemeet volgens Christelike waardes, mag dit sy toekoms versier en bekroon. Vir ons omsluit die naam "Stoker" ook die Stoker-gesin.

Ons opregte dank hiermee ook aan prof. dr. J. A. L. Taljaard deur wie se vriendelike bemoeiing en hulp die stukke in hierdie nommer bekom is. Langs 'n ander weg as wat hy oorspronklik beplan het, het sy voorneme gelukkig werklikheid geword.

W. N. Coetzee 
Opgedra aan

prof. dr. H. G. Stoker 